DOI https://doi.org/10.30525/978-9934-26-114-5-7

\title{
ШЛЯХИ ФОРМУВАННЯ СТУДЕНТСЬКОГО КОЛЕКТИВУ НА ОСНОВІ ІНДИВІДУАЛЬНО-ТИПОЛОГІЧНОГО ПІДХОДУ
}

\author{
Погоріла І. 0. \\ кандидат педагогічних наук, доцент, \\ дочент кафедри біологіі \\ Національний медичний університет імені О. О. Богомольия \\ м. Київ, Україна
}

Нині в період масштабних змін у суспільстві, в усіх сферах життя людини, в умовах комп'ютерної цивілізації з одного боку і багатьох проблем - 3 іншого, зокрема забруднення довкілля, шкідливих звичок, які набули величезного поширення, саме людина залишається на захисті громадянського суспільства. Проте виникає необхідність у модернізації умов праці (навчання), раціональної їх організації, інформатизації суспільства як соціальної системи.

Метою роботи є окреслення шляхів формування студентського колективу на основі індивідуально-типологічного підходу для підвищення ефективності навчання, збільшення працездатності та збереження біосоціального здоров'я його членів.

В науковій літературі колектив розглядається як група людей, об'єднаних спільною метою, діяльністю, інтересами, потребами, нормами поведінки [1]. Колектив базується на принципах єдності і цілісності, динамічності, діяльності. Ознаками колективу, зокрема студентського $€$ наявність певної організаційної структури, спільність цілей, виконання певних соціальних функцій. В той же час колектив - це мікросоціум, де формуються якості особистості, життєві цінності, норми поведінки, відбувається її соціалізація. Саме тому виникає проблема гармонізації функціонування колективу, зокрема студентського на науковообгрунтованій біосоціальній платформі 3 використанням сучасних комп'ютерних технологій [2]. Оптимізація студентського колективу можлива 3 урахуванням знань про біосоціальну структуру особистості його членів, а саме знання про себе, власні можливості [3].

Відомий вчений П. Капіца висловив думку щодо взаємозв'язку науки про вищу нервову діяльність та науки про закони, на яких базується організація суспільства. На його думку організувати навчання і виховання людини, створити ефективну структуру суспільства можна тільки на науковій основі. 
В умовах сьогодення набуває поширення персонологія як галузь знань та дослідження. Дослідник В. Налімов висловив думку про важливість вивчення людини, іiі особистісних властивостей, розуміння іiі поведінки, взаємовідносин з іншими членами суспільства.

Про доцільність вивчення самої людини говорив ще у 1931 році видатний вчений І.П. Павлов. Проте саме зараз виникає потреба у системному, цілісному, міждисциплінарному, ритмологічному, динамічному вивченні людини на основі індивідуально-типологічного підходу. Саме такий підхід сприятиме розвитку людини у суспільстві, формуванню високих людських якостей, зокрема емпатії, комунікації, раціональності, лабільності, реалізації творчого потенціалу.

Сучасна людина, людина XXI ст. повинна бути фізично і морально здоровою, високодуховною, культурною, компетентною, освіченою, конкурентноспроможною, яка володіє знаннями про себе i власні індивідуально-типологічні адаптаційні можливості, тобто біосоціальною культурою.

Саме в умовах глобалізації і технічного прогресу актуальності набуває проблема персоналізації. I саме від біосоціальної культури людини буде залежати майбутне існування усього людства. Тому важливим завданням науковців $є$ проблема біосоціальної освіченості людства, розуміння себе і довкілля, що дозволить кожній людині якісно прожити життя, реалізувати власні якості, взаємодіяти 3 іншими членами соціуму, вміти створювати зону комфорту При цьому важливе розуміння людини на усіх рівнях, а саме генетичному, фізіологічному, біохімічному. Ці знання дозволять також передбачити дії людини в екстремальних умовах, стресових ситуаціях [3].

В контексті вищезгаданого на перший план виступає особистість, іiі структура, поведінка [4]. Багато праць, зокрема Гіппократа, Клавдія Галена, в яких розглядається структура особистості, присвячені вивченню темпераменту. Завдяки яким було виділено 4 типи темпераменту, а саме холерик, сангвінік, флегматик, меланхолік. За І.П. Павловим, видатним вченим минулого століття, сильний, неврівноважений, рухливий - холерик; сильний, врівноважений, рухливий - сангвінік; сильний, врівноважений, інертний - флегматик; слабкий, неврівноважений, інертний - меланхолік. Дослідники Б.М. Теплов, В.С. Мерлін, В.Д. Небиліцин у своїх наукових працях акцентували увагу на значенні властивостей нервових процесів збудження і гальмування для розуміння індивідуальних властивостей людини. Симпатичний відділ відповідає за сильну нервову систему, а парасимпатичний відділ за слабку. У людей 3 домінуючим процесами гальмування - 
парасимпатикотонія, a 3 переважанням процесів збудження симпатикотонія [5].

До загальних властивостей особистості належать активність, емоційність, емоційна стійкість. Організацію нервових процесів визначає поняття «активність», яка пов'язана 3 рівнем кіркового збудження, інтро-і екстраверсією. Емоційність виявляється при схильності до стресу [6].

Вчений-психолог Г. Ю. Айзенк пояснював поведінку людини належністю їі до двох основних типів, а саме інтроверсія-екстраверсія та нейротизм-стабільність, а також до однієї з категорій, що базуються на особливостях нервової системи [7]. На думку Г.Ю. Айзенка інтроверсія, екстраверсія, нейротизм генетично детерміновані. Якщо показники надто високі чи надто низькі, це призводить до патологічних змін в організмі. Посилення нейротизму та інтроверсії виявляється у нав'язливих страхах. Високий рівень нейротизму на фоні високої екстраверсії призводить до істерії. Нервозність виявляється у формі емоційної, пізнавальної та рухової активності.

Якщо, згідно визначення, темперамент характеризує особливості психічної діяльності особистості, відображає засіб реалізації ії дій, то характер виступає як основа поведінки особистості [8]. Наукові праці Л.М. Собчик з співавторами присвячені психофізіологічній структурі особистості як єдності біологічних і соціальних факторів [9].

Для оцінки структури особистості і iï функціонального стану при формуванні студентського колективу доцільно використовувати відомі тестові методики в широкій комп'ютерізації, зокрема тест Люшера, методику експрес-діагностики характерологічних особливостей особистості (опитувальник Айзенка), біоритмологічний тест Естберга, його спрощений варіант, активометричну методику Амінєва, диференційнодіагностичний опитувальник (ДДО) тощо. Особливо це важливо робити на першому курсі, коли формування групи i міжособистісні відносини в них, проходить процес адаптації студента, закладаються профорієнтаційні основи, відбувається становлення професіонала.

Отже, завдяки вищезгаданим методикам 3 використанням ком'ютерних систем можна отримати соціопсихофізіологічний портрет особистості, а саме індивідуально-типологічні властивості, емоційний фон, стиль міжособистісних відносин тощо. Враховуючи типологічні властивості кожного студента і соціопсихофізіологічні особливості колективу в цілому доцільно диференційовано і раціонально підійти до розв'язання проблем, які можуть виникнути у перший рік навчання, зокрема пристосування студента до нового статусу, навантажень, до визначення стратегії і тактики розвитку студентського колективу. 
Останнє в свою чергу сприятиме його гармонізації, покращенню психологічного мікроклімату, комфортному середовищу для навчання i відпочинку, адаптації студента-першокурсника. С можливість вчасно надати рекомендації щодо індивідуалізації навчання, вибору режимів праці і відпочинку, спеціалізації, оптимізації міжособистісних відносин.

\section{Література:}

1. Словник - довідник 3 професійної педагогіки / за ред. А.В. Семенової. - Одеса: Пальміра, 2006. - С. 85.

2. Кузьміна К.І. Інноваційна педагогічна комп'ютерна технологія оптимізації шкільного колективу в аспекті знань про біосоціальну структуру особистості його членів / К.І. Кузьміна, Т.М. Сьомик, Л.М. Шереметова. ІПС НАНУ/ Проблеми програмування, 2019. № 4. - C. 121-131.

3. Кузьмина К.И. Человек и его биосоциальная культура. Теорія $i$ практика управління сочіальними системами: філософія, психологія, педагогіка, соиіологія. Харків. 2005. № 1. С. 109-120.

4. Копець Л.В. Психологія особистості: навч.посіб. Для студентів вищ.навч.закл. - 2-ге вид. К.: Вид. дім «Києво-Могилянська академія», 2008.- $458 \mathrm{c}$.

5. Суворова В.В. Психофизиология стресса. М.: Педагогика, 1975. $208 \mathrm{c}$.

6. Аболин Л.М. Психологические механизмы эмоциональной устойчивости человека. Казань: Изд. Казанского университета, 1987. $262 \mathrm{c}$.

7. Хьелл Л., Зиглер Д. Теорії личности. 3-е изд. - СПб: Питер, 2013, 607 с. (Серия «Мастера психології»).

8. Педагогіка та психологія вищої школи: навчальний посібник / Л.Г. Кайдалова, І.С. Сабатовська-Фролкіна, Н.В. Альохіна, Н.В. Шварп. - Х.: НФаУ, 2019. - 248 с.

9. Собчик Л.Н. Психология индивидуальности. Теория и практика психодиагностики. СПб: Речь, 2008. 624 с. 